\title{
Is Imaging Time Between two Tc 99m DMSA Scans Sufficient for Reporting as Renal Parenchymal Scarring? Healed Parenchymal Renal Defect After 6 Years
}

\author{
Renal Parankimal Skar Raporlamasında I'ki Çekim Arası Süre Yeterli mi? Altı Yıl Sonra lyileşen \\ Parankimal Skar
}

\author{
Erdem Sürücü1, Yusuf Demir'1, Meral Torun Bayram², Salih Kavukçu², Hatice Durak1 \\ ' Dokuz Eylül university, School of Medicine, Department of Nuclear medicine, Izmir, Turkey \\ 2Dokuz Eylül university, School of Medicine, Departments of Pediatrics, Izmir, Turkey
}

\begin{abstract}
We aimed to report a healed renal parenchymal defect after 6 years in a 9-year-old girl who was being followed for recurrent urinary tract infection (UTI). The first UTI was at the age of two. She was being followed with ultrasonography, urine analysis and urine culture since the first UTI. Technetium-99m dimercaptosuccinic acid (DMSA) scintigraphy was repeated four times up to the present day. She had a renal parenchymal defect reported as parenchymal scarring, which healed 6 years after the first DMSA scintigraphy.

Key words: Kidney cortex necrosis, technetium Tc-99m dimercaptosuccinic acid, urinary tract infections

\section{Özet}

Tekrarlayan idrar yolu enfeksiyonları ile takip edilen 9 yaşındaki hastanın 6 yıl sonra iyileşenrenal parankim defekti sunulmaktadır. illk defa 2 yaşında idrar yolu enfeksyonu tanısı alan ve ultrasonografi, idrar testi ve idrar kültürü ile takip edilen hasta bugüne kadar dört defa Tc-99m DMSA böbrek sintigrafisi ile kontrol edilmiştir. Hastada, ilk DMSA sintigrafisinden 6 yıl sonra, parankimal skar olarak raporlanan böbrek parankim defektinde iyileşme mevcuttu.
\end{abstract}

Anahtar kelimeler: Böbreğin korteks nekrozu, teknesyum Tc 99m dimerkaptosüksinik asid, üriner kanal enfeksiyonları

\section{Case Report}

A 9-year-old girl was referred to our nuclear medicine department for the differential diagnosis of acute pyelonephritis (APN) and renal parenchymal scarring. Vesicoureteral reflux (VUR) was diagnosed when she was at the age of 18 months. At admission of the first Technetium99m dimercaptosuccinic acid (DMSA) scan, she did not have any symptoms, the last urine analysis and urine culture which was 1.5 months ago, were normal. First DMSA scintigraphy was performed when she was at the age of 2.5. A hypoactive area in the superior-lateral of the right kidney was reported (Figure 1) and repeating the scintigraphy after 6 months was recommended to differentiate acute pyelonephritis from renal scarring. Differential kidney functions were $50 \%$ for the right kidney and $50 \%$ for the left kidney. Ultrasonography (USG) was performed to look for any pathology in the superior-lateral part of the right kidney such as a cyst, kidney calculus or dilatation of pelvicalyceal system. However, no pathology was detected. After 6 months, at the age of 3, DMSA scintigraphy was repeated. The hypoactive area described in the previous scan was slightly decreased, but it was still present at the same location (Figure 2). The differential functions were the same as the previous scan. Before the second DMSA scan, the last urine analysis and urine culture, which was 1.5 months ago, were normal. It was again suggested to repeat the DMSA scintigraphy 6 months later for a final decision. 
She was lost for follow up for 2 years and finally she was again referr ed to our clinic for a follow up DMSA scintigraphy at the age of 5 . USG was repeated and the findings were similar with the previous study. Also, there was hypoactivity on the upper pole of the left kidney. However, it was similar to previous study. Before the third DMSA scan, the last urine analysis and urine culture, which was 2 weeks ago, were normal. However, she had still bilateral vesicoureteral reflux. There was still a hypoactive area in the superior-lateral of

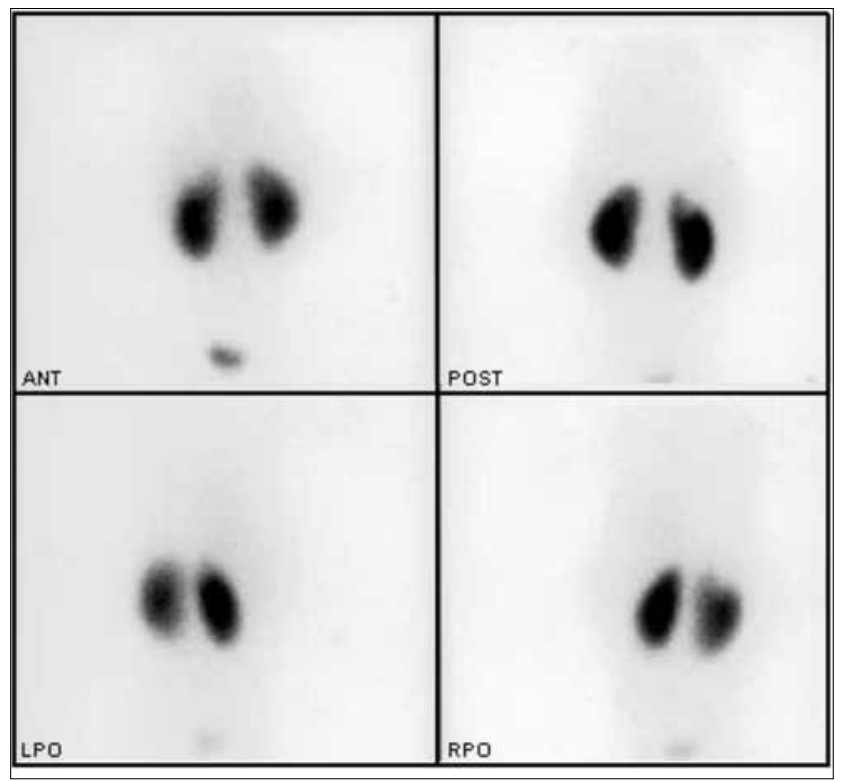

Figure 1. At the age of 2.5, anterior, posterior and oblique projections of the Tc $99 \mathrm{~m}$ DMSA scan show a hypoactive area in the superior-lateral of the right kidney more prominent in the posterior image

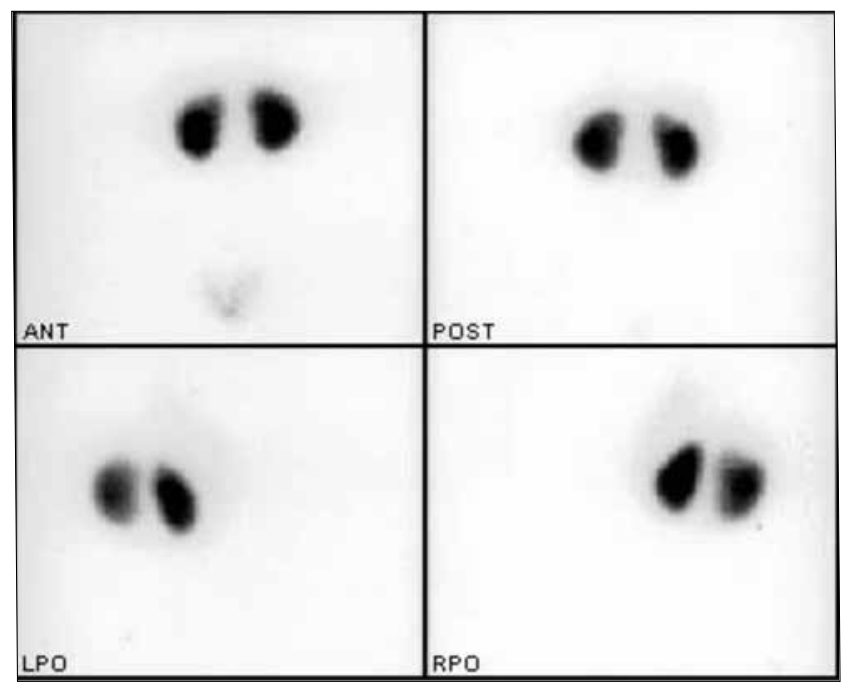

Figure 2. At the age of 3, Tc 99m DMSA scan 6 months later shows that the same hypoactive area in the superior-lateral of the right kidney is still seen in the posterior image the right kidney and finally this area was reported as renal parenchymal scarring (Figure 3). The differential functions were $49 \%$ for the right kidney and $51 \%$ for the left kidney.

Two years after this third DMSA scan, the patient underwent bilateral subureteric injection for persistent vesicoureteral reflux. Evaluation of the therapy outcome for bilateral subureteric injection, she underwent direct vesicoureteral scintigraphy and vesicoureteral reflux was demonstrated in the right kidney. She could not be followed regularly for the next four years and she was again referred to our clinic to evaluate the status of right kidney 4 years

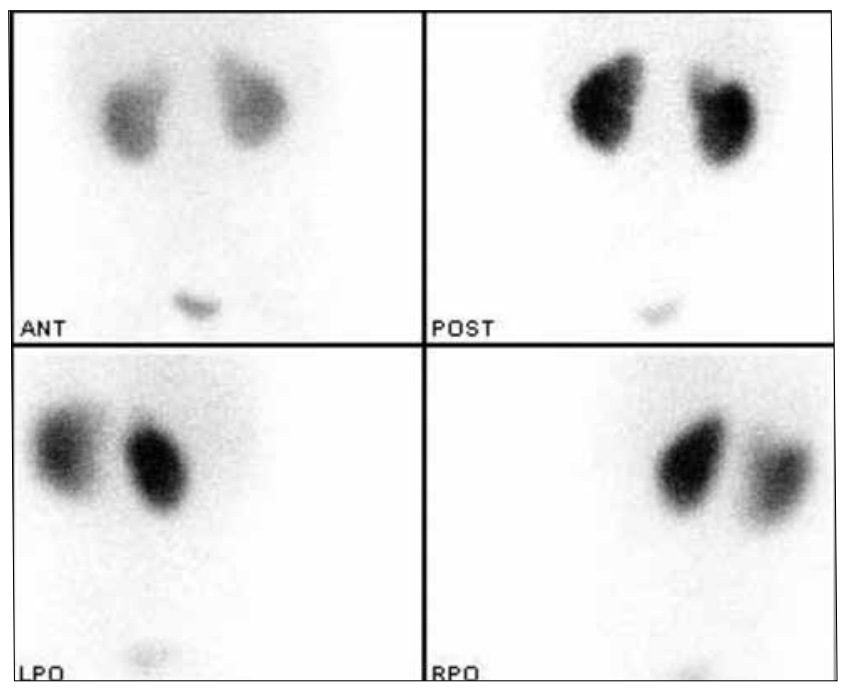

Figure 3. At the age of 5, Tc 99m DMSA scan two years after the second scan reveals that the same hypoactive area in the superior-lateral of the right kidney is persistent and it was reported as renal parencymal scarring. There is also hypoactivity on the upper pole of the left kidney

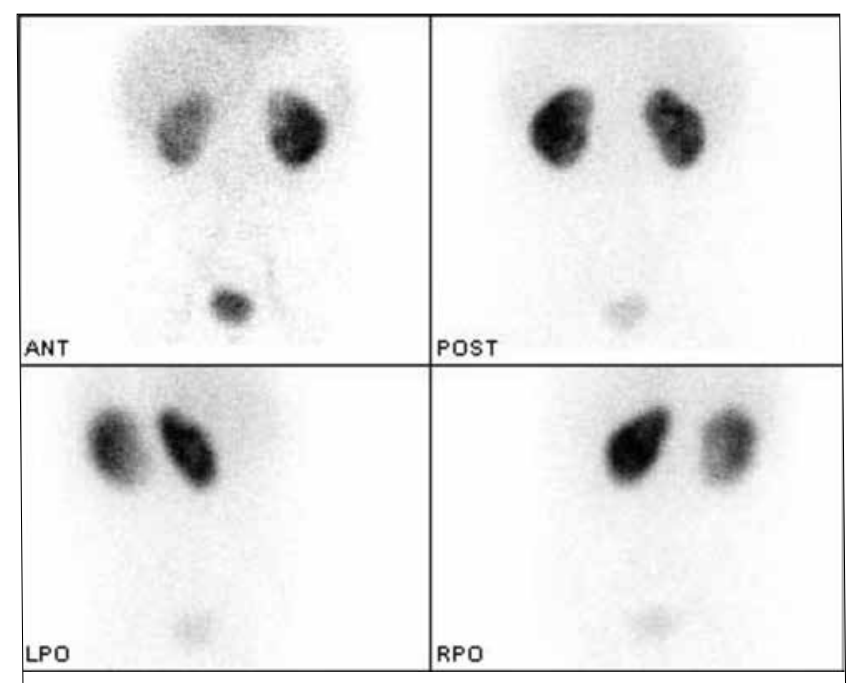

Figure 4. At the age of $9,4^{\text {th }}$ Tc $99 \mathrm{~m}$ DMSA scan shows the superior-lateral of the right kidney is near normal in the posterior image, however there is a mild hypoactive area that can be noticed in the anterior image 
after the third DMSA scan at the age of 9. E. Coli was seen in the last urine culture ( 5 days ago) and there was nitrite and white blood cells in the urine analysis. However she was afebrile, without any symptoms or leukocytosis. It was seen that the hypoactive area in the superior-lateral of the right kidney has almost disappeared (Figure 4). The differential functions were $39 \%$ for the right kidney and $61 \%$ for the left kidney.

\section{Discussion}

UTI is one of the most common important clinical problems in childhood, which occurs in 4-8\% of infants with fever (1). No-specific symptoms in the children can differentiate lower UTI and acute pyelonephritis. It is estimated that $60-65 \%$ of patients with febrile UTI may have APN (2). UTI can affect the renal parenchyma and the children with renal parenchymal involvement are at risk of permanent renal damage that may lead to renal scarring, hypertension, complications during pregnancy and renal failure (3). Renal scarring is present in $8-40 \%$ of patients after an episode of APN $(4,5)$. Experimental $(6,7,8)$ and clinical studies $(9,10)$ showed that the DMSA scintigraphy is probably the most sensitive method for diagnosing and localizing APN. Focal or diffuse reduction of DMSA accumulation develops in APN, however the border of renal parenchyma is protected $(11,12)$. DMSA scan is more sensitive and specific than USG and Intravenous Pyelogram (IVP) for detecting renal parenchymal scarring and follow-up (13). Because DMSA accumulates in functional kidney cells, in contrast to APN, functional cortex is lost in renal parenchymal scarring. Since the recovery time and the severity of the infection can change from child to child, DMSA scan is recommended to be repeated at least 6 months after acute infection (14).

The degree of infection is also important for the choice of treatment and prognosis. DMSA scintigraphy can also help to differentiate the level of the infection. In addition, DMSA scintigraphy is more sensitive than intravenous urography for detecting renal scarring $(15,16)$.

DMSA scintigraphy still seems to be the only imaging tool that can show the progression of the acute damage of renal parenchyma after pyelonephritis and following the development of renal scarring. The proposed repeating time of the scintigraphy for differentiating acute pyelonephritis from renal scarring is variable; the guidelines suggest that it should be at least 6 months (14). If renal damage is still being reported after 6 months, renal parenchymal scarring should be considered. In our case, the persistent hypoactive area described in three successive DMSA scintigraphies suggests renal parenchymal scarring.

One reason of this appearance might be recurrent APN. The patient might have had APN during all of the three DMSA scintigraphies and the hypoactive areas in the kidney might be due to repeated APN. Moreover, there were no clinical infection symptoms such as fever and blood test abnormalities such as increased CRP level, leukocytosis during these DMSA scans and there were not any microorganisms in the urine culture before the DMSA scans. In patients with APN, if there is a reduced Tc-99m DMSA uptake in the scan, clinical infection symptoms or blood test abnormalities should be noticed (17). So, asymptomatic or culture-negative infections can be seen very rarely when there is an abnormal DMSA scan.

Previous studies have shown that the most of the renal scarring was caused by VUR (18). On the other hand, recent studies suggested that scarring may often occur in the absence of VUR (19) and it has been argued that renal scarring may be independent from the presence or absence of VUR (20). Although there was bilateral grade III vesicoureteral reflux in the voiding cystogram before the third DMSA scan, only right kidney had renal parenchymal scarring.

Another point for this case might be related with renal dysplasia, which is characterized by the formation of structural defects of the nephron and collecting ducts accompanied with fibrosis, like scar tissue (21). While the hypoactive area in the superior-lateral of the right kidney improved with growing up of the child, 10\% difference in the differential functions of the kidneys in the last DMSA scan occurred. As the body grows up, dysplasic kidney may not have sufficient functional tissue. This might explain the differences in the differential functions between the kidneys. But contrarily, there was no pathology in two of the USG during the follow-up. Furthermore, USG might have missed out the pathology due to lesion size.

In conclusion, DMSA scintigraphy is still the most sensitive imaging tool to evaluate renal parenchymal scarring and the follow-up. The persistent hypoactive areas in three DMSA scans might be related to persistent infections. Furthermore, because same hypoactivity was seen in three DMSA scans, it was reported as renal parenchymal scarring. Although the optimal time between two Tc-99m DMSA scans for reporting as renal parenchymal scarring is 3-6 months, our patient's renal defect seems to be healed 6 years after the first DMSA scan or at all the times the patient was scanned, the patient had persistent infections.

\section{References}

1. Rushton HG. Urinary tract infections in children: epidemiology, evaluation and management. Pediatr Clin North Am 1997;44:11331169.

2. Hoberman A, Chao HP, Keller DM, Hickey R, Davis HW, Ellis D. Prevalence of urinary tract infection in febrile infants. J Pediatr 1993;123:17-23.

3. Jacobson SH, Eklöf O, Eriksson CG, Lins LE, Tidgren B, Winberg J. Development of hypertension and uraemia after pyelonephritis in childhood: 27 year follow up. BMJ 1989;299:703-706.

4. Benador D, Benador N, Slosman DO, Nusslé D, Mermillod B, Girardin E. Cortical scintigraphy in the evaluation of renal parenchyma changes in children with pyelonephritis. J Pediatr 1994;124:17-20.

5. Ataei N, Madani A, Habibi R, Khorasani M. Evaluation of acute pyelonephritis with DMSA scans in children presenting after the age of 5 years. Pediatr Nephrol 2005;20:1439-1444. 
6. Rushton HG, Majd M, Chandra R, Yim D. Evaluation of 99mTechnetium-dimercapto-succinic acid renal scans in experimental acute pyelonephritis in piglets. Urol 1988;140:11691174.

7. Parkhouse HF, Godley ML, Cooper J, Risdon RA, Ransley PG. Renal imaging with 99Tcm-labelled DMSA in the detection of acute pyelonephritis: an experimental study in the pig. Nucl Med Commun 1989;10:63-70.

8. Wikstad I, Hannerz L, Karlsson A, Eklof AC, Olling S, Aperia A. 99mTechnetium dimercaptosuccinic acid scintigraphy in the diagnosis of acute pyelonephritis in rats. PediatrNephrol 1990;4:331-314.

9. Jakobsson B, Nolstedt L, Svensson L, Soderlundh S, Berg U. 99mTcDimercaptosuccinic acid (DMSA) scan in the diagnosis of acute pyelonephritis in children: relation to clinical and radiological findings. Pediatr Nephrol 1992;6:328-334.

10. Majd M, Rushton HG. Renal cortical scintigraphy in the diagnosis of acute pyelonephritis. Semin Nucl Med 1992;22:98-111.

11. Wallin L Helin I, Baic M. Follow-up of Acute Pyelonephritis in children by Tc-99m DMSA scintigraphy: Quantitative and Qualitive assessment Clin Nucl. Med. 2001;26:423-432.

12. Sayit E, Yılmaz M, Yorulmaz I, Kut Ö, Yürekli Y, Türkmen M, Kavukçu S, Durak H. Çocuklarda tekrarlayan idrar yolu enfeksiyonlarında Tc99m DMSA Sintigrafisi Medical Research 2000;1:17-21.

13. Stokland E, Hellstrom M, Jacobsson B, Jodal U, Sixt R. Reanal Damge one year after first urinary tract infection: role of dimercaptosuccinic acid scintigraphy. J Pediatr 1996;129:815-820.
14. Kıratlı P, Gökçora N, Alan N, Dirlik A, Erbas B, Ergün E, Güngör $F$, Kabasakal L, Özcan Z, Özmen Ö, Sayman H, Türkmen C. Çocuklarda Kortikal Sintigrafi Kilavuzu Turk J Nucl Med 2001;10:167-170.

15. Goldraich NP, Ramos OL, Goldraich IH. Urography versus DMSA scan in children with vesicoureteric reflux. Pediatr Nephrol 1989;3:1-5.

16. Whitear $P_{1}$ Shaw $P_{1}$ Gordon I. Comparison of $99 \mathrm{Tcm}$ dimercaptosuccinic acid scans and intravenous urography in children. Br J Radiol 1990;63:438-443.

17. Elder JS. Nelson Textbook of Pediatrics. Urinary tract infections. In Kliegman RM, Behraman RE, Jenson H.B, Santon BF (eds). 17th ed. Philadelphia, Saunders Elsevier, 2007;1785-1789.

18. Smellie J, Edwards D, Hunter N, Normand ICS, Prescod N. Vesicoureteric reflux and renal scarring. Kidney Int 1975;8:65-72.

19. Jakobsson B, Nolstedt L, Svensson L, Soderlundh S, Berg U. 99mTcDimercaptosuccinic acid (DMSA) scan in the diagnosis of acute pyelonephritis in children: relation to clinical and radiological findings. Pediatr Nephrol 1992;6:328-334

20. Rushton HG, Majd M, Jantausch B, Wiedermann BL, Belman AB. Renal scarring following reflux and nonreflux pyelonephritis in children: evaluation with 99mtechnetium dimercapto- succinic acid scintigraphy. J Urol 1992;147:1327-1332.

21. Elder JS. Nelson Textbook of Pediatrics. Congenital anomalies and disgenesis of the kidney. In Kliegman RM, Behraman RE, Jenson H.B, Santon BF (eds). 17th ed. Philadelphia, Saunders Elsevier, 2007;1783-1785. 